quantitative interplay of the opposed influences upon the individual neuron. Conditions favouring inhibition were discussed.

Though trains of impulses are the sole reactions which enter and leave the central nervous system, it is clear that nervous impulses are not the sole reactions functioning within that system. States of excitement which can sum together, and states of inhibition which can sum together, and states which represent the algebraical summation of these two, are among the central reactions. The specific cell units, the neurons, far from behaving merely as passive recipients and transmitters of impulses, modify as well as transmit what they receive.

\section{Joint Russian-German Expedition to the Pamir.}

A JOINT expedition to the Pamir was organised last year by the Russian Academy of Sciences and the Notgemeinschaft der Deutschen Wissenschaft, consisting of eleven German members and about thirty Russians representing various branches of science, under the leadership of N. P. Gorbunov. The expedition started in June from Osh (in Turkes. tan) and went through Gultcha into the Alai valley, then across the Transalai ridge to the alpine lake Kara-kul ; from there various sections of the expedition radiated in different directions, and the field work went on until November. Scientific results of the expedition will take some time to work out fully, but a preliminary account, as published in the Information Bulletin of the Russian Academy (No. 3-4, for 1929), already gives some idea as to their value.

The geographical section of the expedition collected exhaustive information on the areas traversed. Of particular interest was a study of Fedtchenko's glacier, which has been found to extend for more than $75 \mathrm{~km}$., that is, it ranks amongst the largest glaciers in the world. The topographical section accomplished the enormous task of surveying the wide expanse of Pamir; most of the work had to be done at the altitudes exceeding 4000 metres, which made-it exceedingly difficult. Nine astronomical and twelve triangulation points were determined, and altitudes of twenty-two mountains estimated. The meteorological and geophysical section made regular meteorological, aerological, actinometric and hydrological observations ; 47 geomagnetic points and 150 gypsometric points were determined. The geological section studied the history of the glaciation of the Pamir and prepared a general geological map of the area; the mineralogical collections are very rich and contain proofs of a number of useful minerals.

The zoologists of the expedition collected more than 13,000 animals, mainly insects; it was interesting to find some southern forms at very great altitudes; thus at $3700 \mathrm{~m}$., scorpions, Mutillid wasps, Ammophila, Bombus melamorus, etc., were found. Experiments in hybridisation of Ovis polii with the domestic sheep were made and the progeny will be studied in detail. Apart from the specimens collected, a considerable number of living local animals was sent from the Pamir to the Moscow Zoological Garden. The linguistic section collected materials for a dictionary of the Tadzhik language, made phonograph records of native speech, and studied native customs and folklore. The radio section of the expedition had three transmitting stations at its disposal; apart from keeping in touch with central Russian stations, it made a series of experiments relating to the transmission under the peculiar local conditions. A kinematographic section made about 9000 metres of films of all places and phases of the expedition. The Alpine section made about thirty ascents to the highest peaks of the Pamir, the greatest height reached being $7120 \mathrm{~m}$. (Lenin's peak).

Scientific results of the expedition will be published in parts, as the working out of materials proceeds ; it is suggested that the whole series, which will be published partly in Russian, partly in German, will be completed in 1930, apart from detailed monographs on different problems which will be published separately.

\section{University and Educational Intelligence.}

CAmbridge.-The Harkness Scholarship in geology has been awarded to L. Bairstow, King's College. The Anthony Wilkin Studentship in archeology and anthropology has been awarded to J. B. Charlesworth, of Christ's College.

The following reappointments have been made: F. W. Dootson, University lecturer in chemistry ; P. M. S. Blackett, University demonstrator in physics; R. G. W. Norrish, University demonstrator in chemistry; E. M. Taylor, University lecturer in agricultural chemistry ; E. H. B. Boulton, University lecturer in forestry; H. E. Woodman, University demonstrator in agricultural chemistry; C. E. Tilley, University lecturer in petrology; W. A. Fell, University demonstrator in anatomy ; F. W. Dootson, University demonstrator in chemistry.

Dr. W. M. Smart, of Trinity College, chief assistant at the Observatory, has been reappointed to the John Couch Adams astronomership.

Frank Smart Prizes have been awarded to $H$. R. Barnell, of Downing College, in botany, and to R. J. Pumphrey, of Trinity Hall, in zoology.

The syndicate to consider the organisation and finance of the Botanic Garden has reported to the University. The most important of its recommendations are the following:

(1) The Botanic Garden should become an integral part of the Department of Botany, and the responsible head of the Garden should be the professor of botany.

(2) The duties of the Director of the Garden should be general responsibility for the management of the Garden and particular care for its development as an aid to the study of botany.

(3) The stipend attaching to the office of Director should be variable according to the nature of the other offices held simultaneously by the Director.

(4) A new University lectureship should be created for the teaching of systematic botany.

(5) Consideration should be given to the fact that a part of the land adjoining the Garden could be sold under suitable restrictive conditions without detriment to the present or future needs of the Garden.

(6) The town of Cambridge should be invited to contribute to the cost of the Garden, so long as it is made accessible to the general public.

GLasgow.-Prof. J. W. Gregory, having attained the age of sixty-five years during the past session, has resigned the chair of geology in the University which he has held since 1904. Prof. Gregory is not subject to the age-limit regulation, but he has decided to retire to make way for a younger man and to devote his time to the completion of work in which he has been engaged.

Among others, the honorary degree of LL.D. was conferred on June 19 on: Prof. H. S. Carslaw, professor of pure and applied mathematics, University of Sydney ; Madame Marie Curie, of Paris; The Earl of Elgin, chairman of the Carnegie United Kingdom Trust; C. O. Hawthorne, chairman of the Repre-

No. 3113 , VoL. 123] 
sentative Body of the British Medical Association; and Lord Lugard, ex-Governor of Nigeria.

Lrverpool.-The Council of the University, at its meeting on June 18, elected Dr. D. B. Blacklock, professor of tropical diseases of Africa, to the Walter Myers chair of parasitology. Prof. Blacklock is a graduate of the University of Edinburgh. From 1911 until 1914 he was in turn assistant director and director of the Runcorn Research Laboratory. In 1914 he became a member of the commission appointed to investigate the problems of sleeping sickness in West Africa, and was elected to a lectureship in parasitology in the University of Liverpool. During the War period he was in charge of a pathological laboratory and conducted investigations on malaria on behalf of the War Office. Prof. Blacklock has been secretary and a vice-president of the Tropical Section of the British Medical Association and has played an active part in the promotion of tropical medical research.

At the same meeting the Council appointed Mr. E. C. Titchmarch to the chair of pure mathematics in the University, and Dr. J. H. Orton to the Derby chair of zoology. Mr. Titchmarch, a scholar of Balliol, was appointed in 1923 to a lectureship in mathematics at University College, London, and to a fellowship of Magdalen College, Oxford. Since 1925 he has been reader in mathematical analysis in the University of London. Dr. Orton is a graduate of the Royal College of Science, London. In 1914 he was appointed assistant naturalist at the Marine Biological Labora tory, Plymouth, and after War service returned to the laboratory, in which he was promoted in 1924 to the post of chief naturalist. He has conducted extensive research on problems of marine biology, paying particular attention to the life history of the oyster.

Manchester. - A limited number of research scholarships in technology, each of the value of not more than $£ 100$, are to be awarded in July by the Manchester Municipa] College of Technology. Application forms, returnable by, at latest, July 6, can be obtained from the Registrar of the College.

KING'S CoLLEGE, London, celebrated during the past week the hundredth anniversary of its foundation. The celebrations, inaugurated on Tuesday by their Royal Highnesses the Duke and Duchess of York, included the dedication of the chapel and opening of the library and new wing of the Vincent Square hostel by the Archbishop of Canterbury, who is the official Visitor. Beginning in 1829 with work of university standard in arts, science, and medicine, and a 'junior department' which became the present King's College School at Wimbledon, the growth of the College has been marked by the establishment of an engineering department in 1838, a hospital (now on Denmark Hill) in 1839, a theological department for the training of clergy in 1847, evening classes in 1856, a department for women (in Kensington) in 1885, and a teacher-training department in 1890 . The post-War years have seen a remarkable further enlargement of its activities and increase in the number of its students, with the result that additional accommodation is urgently required, especially in the departments of chemistry and anatomy. The building scheme designed to meet this need at a cost of $£ 125,000$ will, if carried out, improve the architectural amenity of the Thames frontage in the neighbourbood of Waterloo Bridge. For this, and for the endowment of professorial chairs and scholarships the College is asking the public to subscribe to its centenary appeal fund.

No. 3113 , Vor. 123]

\section{Calendar of Patent Records.}

June 29, $1722 .-A$ patent was granted on June 29, 1722, to Martin Triewald, the Swedish engineer, for his invention of a "certain engine or machine for drawing water out of mines and collyeries by the power of the atmosphere". Triewald, who was in England when the first Newcomen engines were being set up and himself helped in the erection of one, built the first engine in Sweden, that for the Dannemora mines, and is the author of the earliest monograph on the steam engine, which was published at Stockholm in 1734. Triewald claims to have made improvements on the engine, but what these were and what was the construction for which his patent was granted he does not say.

July $I, I 769 .-T h e$ stamped brass trade dates from the patent of John Pickering, whose specification was enrolled on July 1, 1769. The invention consisted of a "new method of performing that kind of work commonly called chasing in gold, silver, brass, tin, or other metal, by a machine consisting of an oblong frame with two rods, in which a moving forcer is worked upon a striking block with a die fixed thereon formed for each respective purpose, whereby the work is executed in a much more expeditious manner and far superior to anything of the kind (not being actual chasing) ever yet performed by any other means".

July $\mathrm{r}$, $x 877$. - There was no common patent law for Germany before 1877, but for many years patents had been granted by the constituent States under their respective laws and regulations. The first patent law of the German Empire, superseding the various State laws, came into force on July 1, 1877, and the first patent under it dates from the following day.

July 3, I769. - The practical application of the principle of roller drawing in cotton-spinning is due to Sir Richard Arkwright, whose patent for the invention was sealed on July 3, 1769. Arkwright was partnered and greatly helped in the establishment of the industry which was started at Cromford Mill, Derbyshire, by Jedediah Strutt, the inventor of the rib stitch hosiery frame.

July 3 , r86x. - The manufacture of mechanical wood-pulp for papermaking was the invention of F. G. Keller in 1845 , but its commercial introduction and development are mainly due to Heinrich Voelter, papermaker, of Heidenheim, who was granted a Prussian patent for five years for his improved process on July $3,1861$.

July 4, I 767 .- On July 4, 1767, there was granted a patent to John Winn, a shipwright of Shadwell, for a method of saving life "in case of a ship being in distress on a lee shore where a boat cannot live". Ropes were sent ashore by means of a buoy, and the passengers and crew were then transported in a basket slung on one of the ropes and hauled to the shore.

July 6, 1897.- The patent of Walther Nernst, of the University of Gottingen, for the electric lamp which is known by his name, was granted in Germany on July 6, 1897. At the time of its introduction, practically no improvement had been made in the earlier carbon filament lamp, other than in the details of the manufacturing processes, and Nernst utilised for his lighting element one of the refractory rareearths, which allowed a current to pass after a preliminary heating, and withstood a greatly increased temperature. He succeeded in reducing the consumption from the 4 watts per candle power of the carbon filament to 1.5 watts. The lamp has now been very largely displaced by the metal filament lamp. 